\title{
Improved Irrigation Management of Sweet Orange with Huanglongbing
}

\author{
Said A. Hamido ${ }^{1}$, Kelly T. Morgan, and Robert C. Ebel \\ Southwest Florida Research and Education Center, University of Florida, \\ 2685 SR 29 N, Immokalee, FL 34142
}

\section{Davie M. Kadyampakeni}

Citrus Research and Education Center, University of Florida, 700 Experiment Station Road, Lake Alfred, FL 33850

Additional index words. Florida Automated Weather Network (FAWN), Huanglongbing (HLB), leaf area index, sap flow, soil available water content, stem water potential

\begin{abstract}
Because of the decline in production and negative economic effects, there is an urgent need for strategies to reduce the impact of Huanglongbing (HLB) on citrus [Citrus $\times$ sinensis (L.) Osbeck]. The objective of this study was to evaluate the impact of different irrigation schedules on total available soil water (TAW) and water uptake characteristics of citrus trees affected by HLB in central and southwest Florida. The study was initiated in Jan. 2014 for 2 years on 5-year-old sweet orange trees located in three commercial groves at Arcadia, Avon Park, and Immokalee, FL. Each grove had three irrigation scheduling treatments including the University of Florida, Institute of Food and Agricultural Sciences (UF/IFAS) recommendations, Daily irrigation, and an Intermediate treatment. All groves received similar volumes of water per week based on evapotranspiration (ET $)$ reported by the Florida Automated Weather Network. Sap flow (SF) measurements were taken for two trees per treatment for at least $\mathbf{1 0}$ days per site (twice/year). During those periods, leaf area, leaf area index (LAI), and stem water potential $(\Psi)$ were determined. Also, TAW was determined using drainage curve and capacitance soil moisture sensors installed at incremental soil depths of $0-15,15-30$, and $30-45 \mathrm{~cm}$. Results showed significant differences in average SF, LAI, $\Psi$, and TAW measurements among treatments. Diurnal SF value under daily irrigation treatment increased by $91 \%, 51 \%$, and $105 \%$ compared with UF/IFAS irrigation in Arcadia, Avon Park, and Immokalee, respectively. Soil water contents (WCs) under daily treatment increased by $59 \%, 59 \%$, and $70 \%$ compared with UF/IFAS irrigation treatment in Arcadia, Avon Park, and Immokalee, respectively. Our results indicated that daily irrigation improved tree water dynamics compared with IFAS or Intermediate irrigation scheduling treatments and reduced tree stress with the same volume of water.
\end{abstract}

Citrus greening or HLB, caused by Candidatus Liberibacter asiaticus (CLas), is the most fatal and quickly spreading citrus disease worldwide (Garnier and Bove, 1983; Gonzalez et al., 2012; Jagoueix et al., 1994). Citrus [Citrus $\times$ sinensis (L.) Osbeck] trees affected by this disease decline in productivity and produce deformed and inedible fruit (Hall and Gottwald, 2011). Currently, there is no known cure for HLB (Raithore et al., 2015), and it has spread throughout the entire state of Florida with an estimated $80 \%$ of citrus trees affected (Singerman and Useche, 2015).

Due to the threat of reduced production and negative economic impacts, there is an urgent need for strategies to manage HLB without severely depleting our resources including water. Water is a limiting factor in crop production, particularly in Florida with predominantly sandy soils in citrusproducing regions. During the last six decades, water demands for irrigated crops have

Received for publication 7 Apr. 2017. Accepted for publication 11 May 2017.

${ }^{1}$ Corresponding author. E-mail: shamido@ufl.edu. increased (Maupin et al., 2014). In the United States, irrigated agriculture consumes more than $80 \%$ of total water used and contributes to more than $45 \%$ of the total agricultural production costs (Schaible and Aillery, 2012). Recently, the Southwest Florida Water Management District has reported that more citrus growers are exceeding their monthly and yearly permitted water allocations (Ferguson, 2015).

In addition to plant characteristics associated with plant age, health, and structure, SF is impacted by environmental factors including air temperature and soil water availability. Soil water availability is mainly affected by a series of factors including soil physical and chemical properties (e.g., soil texture, structure, organic matter content, and topography), climate factors (e.g., temperature, solar radiation, and rainfall), and vegetation cover. Soil water availability may also affect evapotranspiration by reducing water uptake (Morgan et al., 2006). However, studies investigating relationships between soil moisture and SF can be confusing. Various studies have reported a limited effect of soil moisture on crop SF (Granier et al., 2000; O'Brien et al., 2004). Conversely, others have reported a negative relationship between soil moisture and SF (Holscher et al., 2005).

In Florida, citrus groves are typically planted in areas with sandy soils with low water-holding capacities and organic matter contents. Irrigation strategies that allow growers to increase fruit production without depletion of water resources must be documented and practiced. Scientists are facing tremendous challenges for increasing water efficiency in citrus production systems as a consequence of HLB (Kadyampakeni et al., 2014). Improved water-use efficiency may be achieved by using the proper irrigation schedule (Fereres and Soriano, 2007).

Improving irrigation management is a vital factor in developing sustainable agricultural practices (Fernandez et al., 2008). In addition, there are increasing concerns about the availability of water that must be used in agricultural production (Fereres and Gonzalez-Dugo, 2009; Fernandez et al., 2008). During the last few decades, environmental concerns over water scarcity have stimulated research to invest into new irrigation technologies and more efficient scheduling approaches (Fernandez et al., 2008). Various methods for irrigation scheduling under different crops have been tested. Many of them rely mainly on nondestructive SF measurements (Fernandez et al., 2008; Jones, 2004). Thus, SF measurements play an important role in understanding the dynamics of plant water flow in irrigated crops (Smith and Allen, 1996). The use of nondestructive SF and $\Psi$ measurement methods are exceptionally suited for determining crop water status in irrigation scheduling studies (Ballester et al., 2013).

Investigating improved irrigation practices for HLB-affected trees has not been conducted in Florida or other areas where greening occurs. It has been documented that HLB-affected trees have lower root densities than healthy trees (Hamido et al., 2016; Kadyampakeni et al., 2014), reducing the ability of the tree to take up water and nutrients from dryer soils compared with healthy trees. Thus, field scale experimentation is needed to determine if current citrus irrigation practices need to be changed for citrus trees with HLB. The combination of experiments and demonstrations in a wide range of soils and areas of the state would improve the applicability and adoption of improved irrigation management recommendations. Thus, the objective of this study was to determine the impact of irrigation scheduling on growth and water relations of HLBaffected citrus trees.

\section{Materials and Methods}

\section{Experimental sites and irrigation} schedules

The experiment was conducted from 1 Jan. 2014 to 27 Aug. 2015 on 12-year-old sweet orange [Citrus $\times$ sinensis (L.) Osbeck] trees located in three commercial groves: 1) Arcadia, FL $\left(27.22^{\circ} \mathrm{N}, 81.86^{\circ} \mathrm{W}\right)$ in a valkaria fine sandy soil (Siliceous, hyperthermic 
Spodic Psammaquents, $0 \%$ to $2 \%$ slope) with tree spacing of $3.96 \times 7.01 \mathrm{~m}$; 2) Avon Park, FL $\left(27.59^{\circ} \mathrm{N}, 81.50^{\circ} \mathrm{W}\right)$ in a basinger fine sand (Siliceous, hyperthermic Spodic Psammaquents, $0 \%$ to $2 \%$ slope) with tree spacing of $3.35 \times 7.01 \mathrm{~m}$; and 3) Immokalee, FL $\left(26.42^{\circ} \mathrm{N}, 81.42^{\circ} \mathrm{W}\right)$ in Immokalee fine sandy soil (Sandy, siliceous, hyperthermic Arenic Alaquods, $0 \%$ to $2 \%$ slope) with tree spacing of $3.66 \times 8.84 \mathrm{~m}$.

Before establishment of the experiment, leaf samples were collected for polymerase chain reaction analysis as per the method of Handique et al. (2012) for CLas and confirmation of HLB existence during Oct. 2013. Three irrigation treatments were applied to selected HLB-affected trees at each site: 1) The current UF/IFAS-recommended irrigation schedule based on citrus evapotranspiration (ET) reported by the nearest FAWN (the UF/IFAS-recommended schedule is based on $25 \%$ to $50 \%$ reduction in TAW resulting in variable irrigation frequencies from daily to every $10-14$ d); 2) a Daily irrigation schedule based on the same daily crop ET determined in treatment one (Daily); and 3) an Intermediate schedule based on ET that would be half the interval between the two irrigation scheduling methods in treatments 1 and 2 (Intermediate). Irrigation duration for each treatment was calculated to supply similar volumes of water on a daily average.

\section{Water relations measurements}

Soil moisture. Soil water content was measured every $30 \mathrm{~min}$ during the experimental period from Jan. 2014 to Aug. 2015 using data logger EM 50 (Decagon Devices, Pullman, WA) at incremental soil depths of $0-15,15-30$, and $30-45 \mathrm{~cm}$. Soil moisture was measured using EC-5 soil moisture sensors at $0-15-$ and $15-30-\mathrm{cm}$ depths and an HS-10 sensor at the 30-45-cm depth (Decagon Devices). Total available water was calculated using the drainage release curve for each soil depth at all sites using Eq. [1].

$\mathrm{TAW} \%=[(\mathrm{WC}-\mathrm{FC}) /(\mathrm{FC}-\mathrm{PWP})] * 100$

where, TAW is the total available water, WC is the soil water content, FC is the field capacity, and PWP is the permanent wilting point.

Stem water potential. Stem water potential was measured during dry and wet seasons of 2014 and 2015 (Table 1) using a Portable Plant Water Status Console (Model 3115; Soilmoisture Equipment Corp, Santa Barbara, CA). Stem water potential was measured as recommended by the manufacturer and other researchers (Morgan et al., 2014). Four representative leaves per tree (two trees per treatment) were randomly selected $24 \mathrm{~h}$ before measurements and covered with a thin film of plastic and aluminum foil to allow the water potential of the leaves to equilibrate with the water potential of the stem. A sharp razor was used to cut leaf petioles close to the
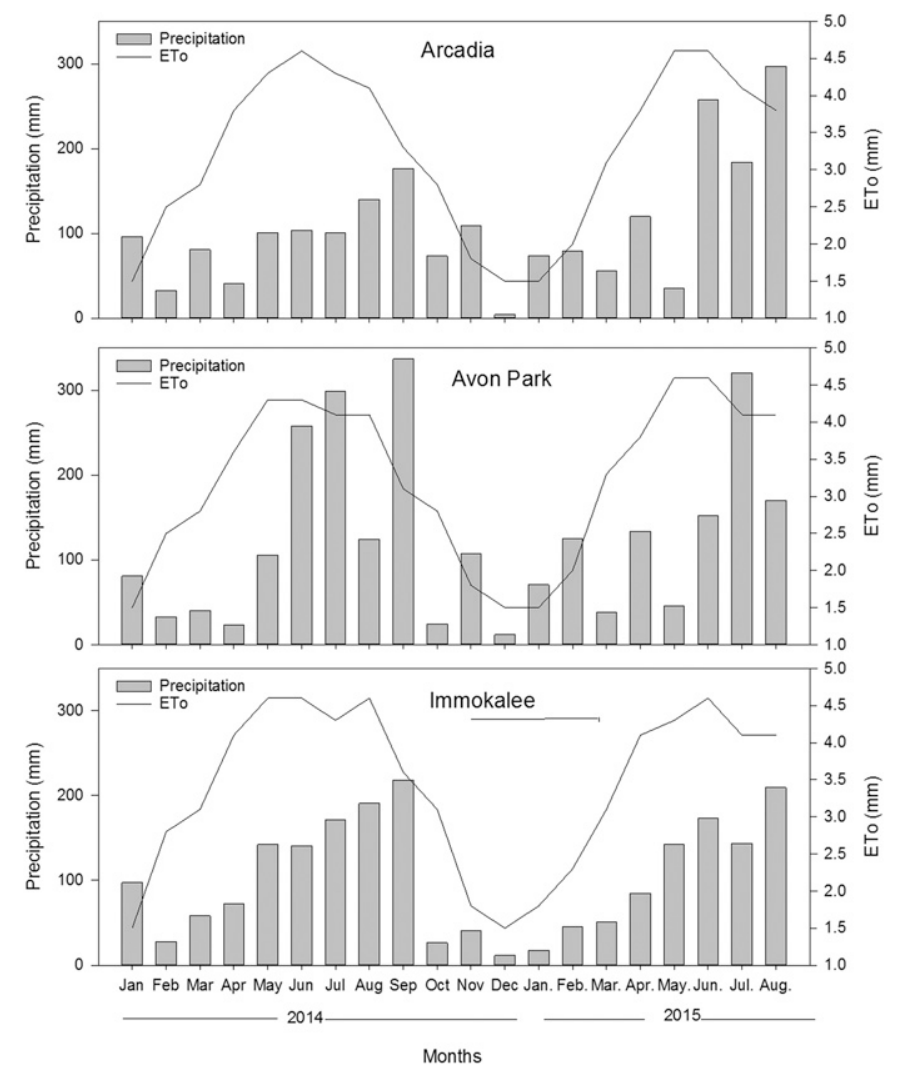

Fig. 1. Evapotranspiration and precipitation at selected commercial sites in the southwest and central Florida during nonrainy cycles during the study between Jan. 2014 and Aug. 2015.

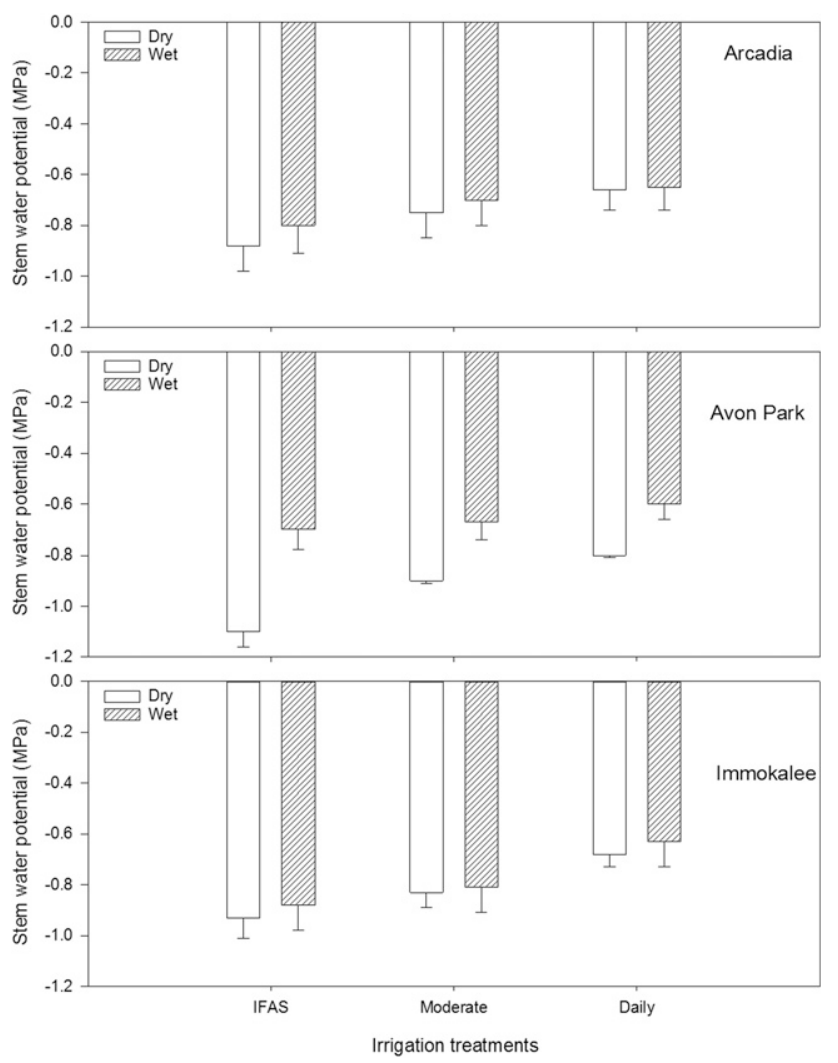

Fig. 2. Effect of irrigation treatment (Daily, Intermediate, and UF/IFAS) on stem water potential during 2014 and 2015 at three commercial sites in the southwest and central Florida during 2014. Bars with similar letters are not significantly different at $\alpha<0.05$. Bars represent the standard error of four replicates. 
Table 1. Duration and time of each field measurements at selected commercial sites.

\begin{tabular}{|c|c|c|c|c|c|}
\hline \multirow[b]{2}{*}{ Site } & \multicolumn{2}{|c|}{ Sap flow } & \multirow[b]{2}{*}{ Stem water potential } & \multirow[b]{2}{*}{ Leaf area } & \multirow[b]{2}{*}{ Leaf area index } \\
\hline & Start date & End date & & & \\
\hline Immokalee & 17 Feb. & 28 Feb. & 18 Feb. & 13 Feb. & $18 \mathrm{Feb}$. \\
\hline Arcadia & 3 Mar. & 17 Mar. & 4 Mar. & 4 Mar. & 4 Mar. \\
\hline Immokalee & 20 June & 1 July & 13 May & 1 July & 13 May \\
\hline Arcadia & 7 July & 15 July & 15 July & 15 July & 23 July \\
\hline Avon Park & 15 July & 24 July & 24 July & 24 July & 23 July \\
\hline Immokalee & 21 Apr. & 1 May & 22 Apr. & 1 May & 1 May \\
\hline Arcadia & 4 May & 12 May & 5 May & 12 May & 12 May \\
\hline Avon Park & 13 May & 27 May & 14 May & 27 May & 12 May \\
\hline Immokalee & 4 Aug. & 10 Aug. & 5 Aug. & 5 Aug. & 10 Aug. \\
\hline Arcadia & 11 Aug. & 19 Aug. & 13 Aug. & 19 Aug. & 14 Aug. \\
\hline Avon Park & 19 Aug. & 26 Aug. & 20 Aug. & 26 Aug. & 20 Aug. \\
\hline
\end{tabular}

Table 2. Means and analysis of variance (ANOVA) for the effect of irrigation treatment on total available water content (\%) by irrigation treatment at different soil depths at selected sites in the southwest of Florida.

\begin{tabular}{|c|c|c|c|c|}
\hline \multirow[b]{2}{*}{ Irrigation treatment } & \multirow[b]{2}{*}{ Soil depth $(\mathrm{cm})$} & \multicolumn{3}{|c|}{ Commercial site } \\
\hline & & Arcadia & Avon Park & Immokalee \\
\hline & $0-15$ & $68.9 \mathrm{~cd}$ & $80.7 \mathrm{~b}$ & $68.1 \mathrm{bc}$ \\
\hline \multicolumn{5}{|l|}{ Intermediate } \\
\hline & $0-15$ & $52.2 \mathrm{fg}$ & $56.3 \mathrm{~cd}$ & $64.5 \mathrm{c}$ \\
\hline & $15-30$ & $58.9 \mathrm{ef}$ & $61.4 \mathrm{c}$ & $46.6 \mathrm{~d}$ \\
\hline & $0-15$ & $48.1 \mathrm{~g}$ & $49.7 \mathrm{~d}$ & $46.6 \mathrm{~d}$ \\
\hline & $15-30$ & $80.9 \mathrm{~b}$ & $50.4 \mathrm{~d}$ & $32.1 \mathrm{e}$ \\
\hline & $30-45$ & $62.3 \mathrm{de}$ & $61.9 \mathrm{c}$ & $69.3 \mathrm{bc}$ \\
\hline \multicolumn{5}{|c|}{ ANOVA } \\
\hline & & Arcadia & Avon Park & Immokalee \\
\hline Source of variation & & $\operatorname{Pr}>F$ & $\operatorname{Pr}>F$ & $\operatorname{Pr}>F$ \\
\hline
\end{tabular}

Means in the same column with the same letter are not significantly different at $\alpha \leq 0.05$.

Table 3. Means and analysis of variance for the effect of irrigation treatment on selected trees parameters during dry and wet seasons at selected sites in Florida.

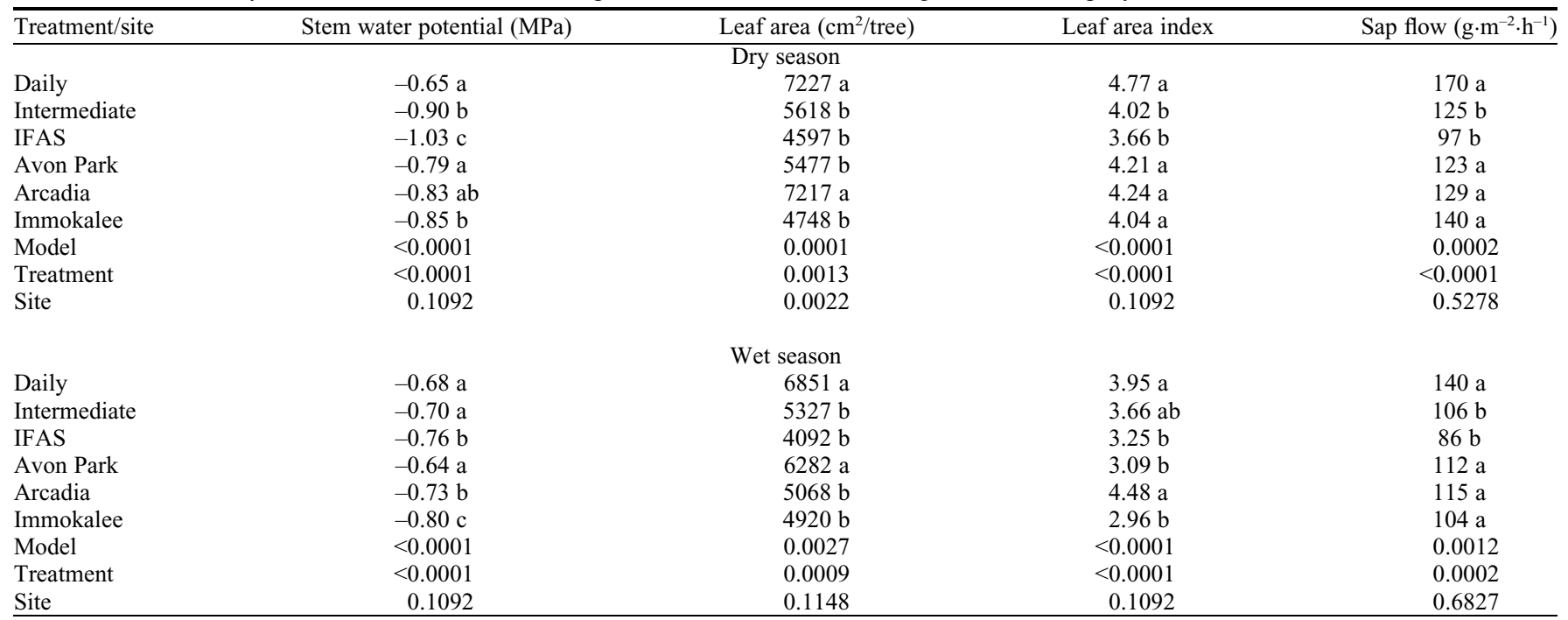

Means in the same column with the same letter are not significantly different at $\alpha \leq 0.05$. 
Dry season

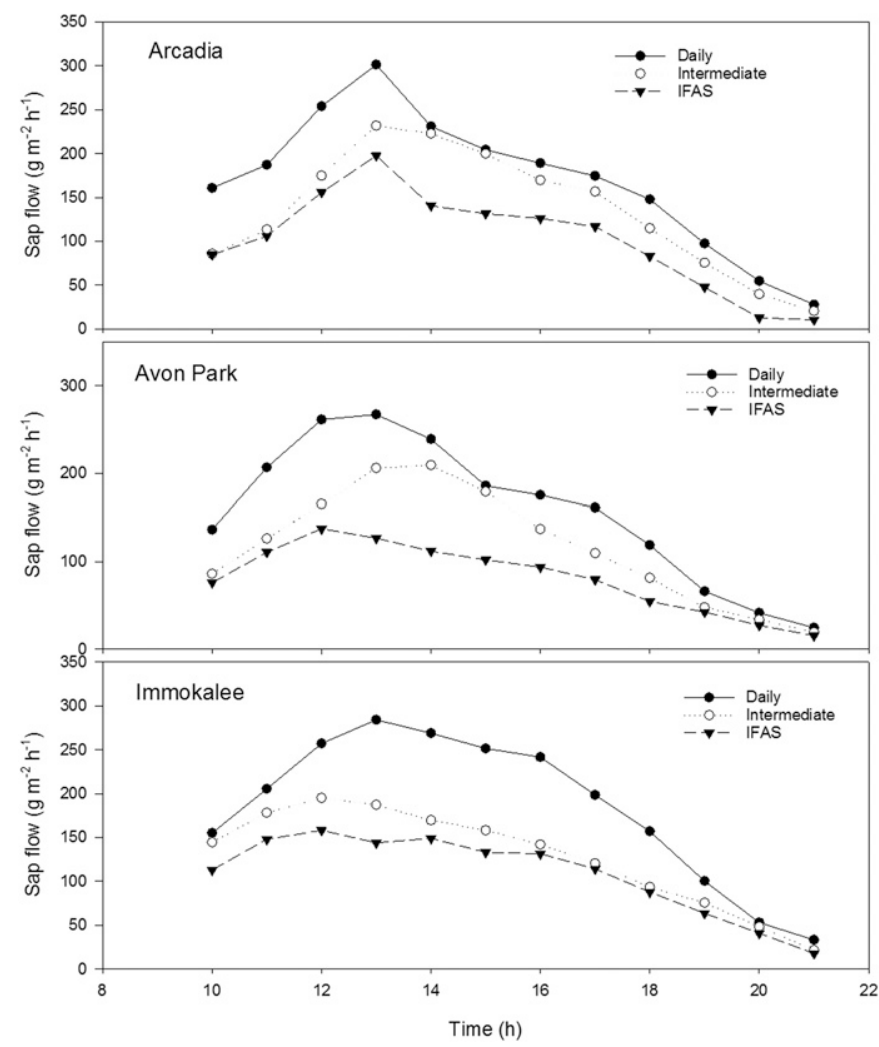

Fig. 3. Effect of irrigation treatment (Daily, Intermediate, and UF/IFAS) on hourly sap flow measurements at commercial sites in the southwest and central Florida during dry seasons of 2014 and 2015.

Wet season

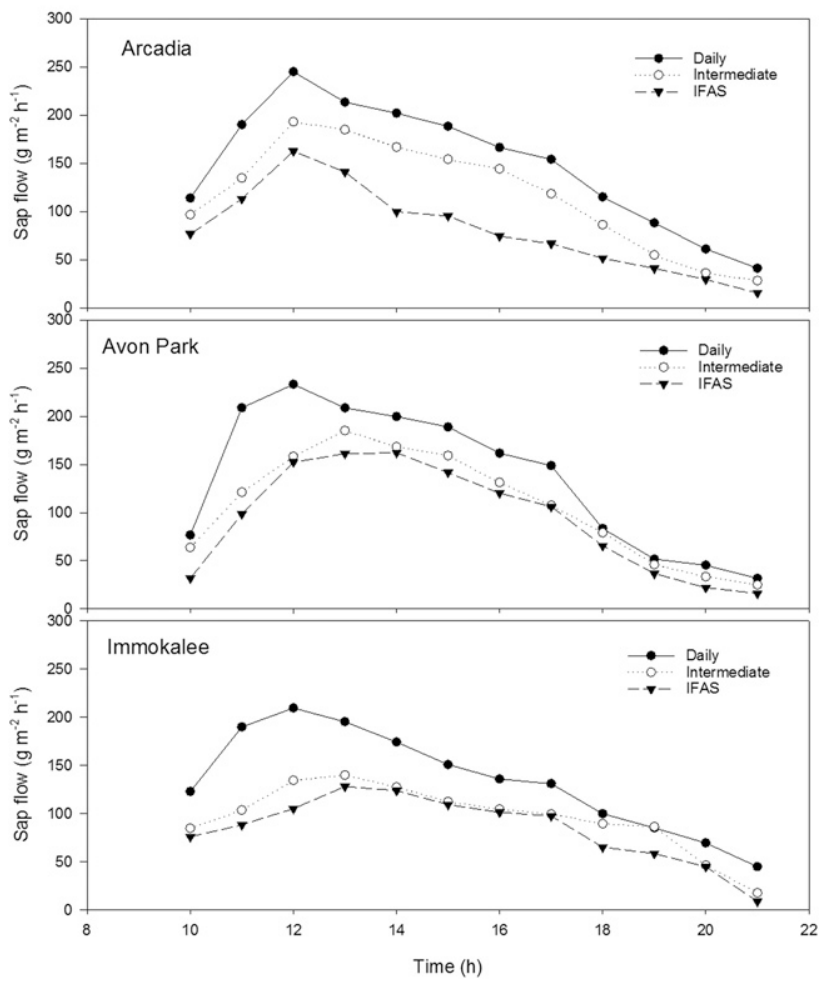

Fig. 4. Effect of irrigation treatment (Daily, Intermediate, and UF/IFAS) on hourly sap flow measurements at three commercial sites in the southwest and central Florida during wet seasons of 2014 and 2015. stem and placed into the pressure chamber immediately to avoid any biological and/or physical changes. The chamber was pressurized at $1 \mathrm{MPa} / 30 \mathrm{~s}$ using compressed nitrogen until the discharge of water from the petiole became visible, and the pressure was recorded in MPa (Morgan et al., 2014; Soil Moisture Equipment Corp., 2006).

Sap flow. Sap flow measurements were conducted four times between Feb. 2014 and Aug. 2015 including dry and wet seasons (Table 1) as measured by the heat balance method using an automated Flow32-1K flow system (Dynamax Inc., Houston, TX) connected to stem heat balance gauges (SGA13, SGB16, SGB19, and SGB25; Dynamax). Stem diameters ranged from 13 to $24 \mathrm{~mm}$. Gauges were installed at least $120 \mathrm{~cm}$ above the soil surface. Gauge installation was performed as described by the manufacturer (Dynamax, 1990). Stems were coated with silicon grease (Dow Corning 4; Dow Corning, Midland, MI) to enhance thermal contact and avoid stem damage. Sap flow measurements were taken on two trees per treatment with three sensors per tree.

Leaf area and leaf area index. During SF measurements, leaves were counted on two trees for each treatment on the branches holding the SF sensors. Average individual leaf area was estimated by sampling 10 representative leaves at different points within the canopy of each tree for a total of 20 leaves per treatment. Individual leaf area was determined using a portable leaf area meter (LI-3000A; LI-COR, Lincoln, NE). Calculated leaf area was used for SF measurements only. Leaf area index was measured twice per year (dry and wet seasons) for 2 years during a sunny day in four directions per tree and then averaged. Leaf area index was determined for 10 trees of each treatment using a SunScan Canopy Analysis System as recommended by the manufacturer (Dynamax Inc.).

\section{Statistical analysis}

Represented data are the average of a 2-year study. Significant effects were determined by analyses of variance (ANOVAs) performed with SAS 9.3 using the PROC GLM procedure (SAS Institute, 2007). The least significant difference test was used to determine significant differences among means at $P \leq 0.05$. Each site was analyzed separately as a randomized complete block design. Correlations among all variables were fitted using Sigma Plot 12.3 software (Systat Software, 2009).

\section{Results and Discussion}

Meteorological conditions. Average daily air temperatures, solar radiation, and reference evapotranspiration $\left(\mathrm{ET}_{\mathrm{o}}\right)$ for FAWN station within $10 \mathrm{~km}$ of experimental site did not vary significantly among locations from Jan. 2014 to Aug. 2015 (Fig. 1). Average daily $\mathrm{ET}_{\mathrm{o}}$ values among locations ranged between 3.4 and $3.7 \mathrm{~mm}$. Average daily solar radiation in Arcadia and Avon 

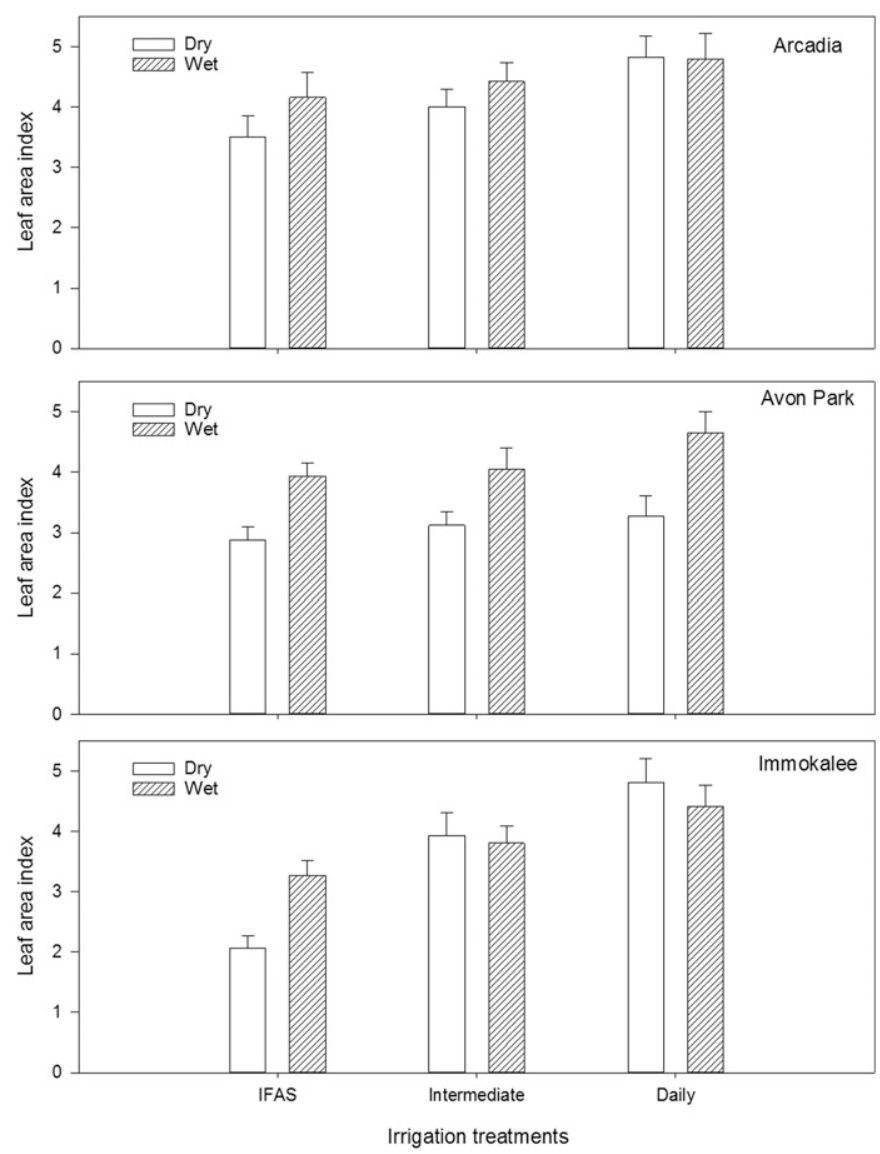

Fig. 5. Effect of irrigation treatment (Daily, Intermediate, and UF/IFAS) on leaf area index during 2014 and 2015 at three commercial sites in the southwest and central Florida during 2014. Bars with similar letters are not significantly different at $\alpha<0.05$. Bars represent the standard error of 10 replicates.

Park was similar for both years; however, solar radiation in Immokalee declined by $9 \%$ from 226 (2014) to $206(2015) \mathrm{W} \cdot \mathrm{m}^{-2}$. Precipitation patterns were not uniform during the 2-year period. Cumulative precipitation during the Florida rainy season from March to August increased during the 2 years in Arcadia by $68 \%$ from $94 \mathrm{~mm}$ in 2014 to $158 \mathrm{~mm}$ in 2015, whereas, in Avon Park and Immokalee, rainfall was similar with less than $2 \%$ increase in Avon Park (from 141.7 to $143.3 \mathrm{~mm}$ ) and $3.5 \%$ increase in Immokalee (from 129.3 to $133.92 \mathrm{~mm}$ ) during 2014 and 2015, respectively.

Soil water contents. Significant differences in water content by soil depth among irrigation treatments were detected during the 2 -year study. Each site reacted differently in storing water by depth which may be related to many factors including chemical, physical, and biological soil factors. Across all sites, Daily irrigation promoted storage of more water than Intermediate or UF/IFAS schedules (Table 2). For example, Daily irrigation had significantly higher TAW $(P \leq 0.05)$ in top-soil surface $(0-15 \mathrm{~cm})$ measured to be $68.9 \%, 80.7 \%$, and $68.1 \%$ of $\mathrm{FC}$ when compared with Intermediate $(52.2 \%, 56.3 \%$, and $64.5 \%)$ or IFAS $(48.1 \%, 49.7 \%$, and 46.6\%) in Arcadia, Avon Park, and Immokalee, respectively.

The irrigation treatment $\times$ soil depth twoway interaction for TAW was significant for
Avon Park $(P \leq 0.0001)$ and Arcadia $(P \leq$ $0.0001)$, indicating those sites stored higher the experiment. In general, the TAW measured in Daily schedule represented greater values increased by $14 \%, 18 \%$, and $58 \%$ compared with Intermediate irrigation treatments, and $25 \%, 40 \%$, and $63 \%$ compared with UF/IFAS irrigation treatments in the top 45-cm soil of Arcadia, Avon Park, and Immokalee sites, respectively, indicating that the daily irrigation practice was adequate and caused no water stress. Dryer soil under the UF/IFAS treatment resulted in a significant decrease in water use compared with Intermediate or Daily treatments during the experiment.

Stem water potential. Significant differences in $\Psi$ among irrigation treatments across all sites (Table 3 ) were observed. In Avon Park and Immokalee, the season $\times$ irrigation treatments interaction had a significant effect on $\Psi$, indicating that the trees responded differently in the rainy and nonrainy seasons under different irrigation treatments within the study. However, in Arcadia, that interaction was not significant indicating $\Psi$ was relatively similar among seasons of sampling. Among all irrigation treatments, measured $\Psi$ under Daily irrigation was higher than that under UF/IFAS and/or Intermediate irrigation treatments. volume of water by depth over the period of
Highest $\Psi$ values were reported under daily treatments with averages of $-0.66 \pm$ $0.08,-0.80 \pm 0.01$, and $-0.68 \pm 0.05 \mathrm{MPa}$ in Arcadia, Avon Park, and Immokalee, respectively (Table 3 ). Increases of $2 \%, 25 \%$, and $7 \%$ in $\Psi$ were observed in Arcadia, Avon Park, and Immokalee, respectively. Across seasons, $\Psi$ values for UF/IFAS treatments represented significantly lower values compared with Daily treatment by $25 \%, 20 \%$, and $27 \%$ in dry seasons and $19 \%, 14 \%$, and $24 \%$ during wet seasons in Arcadia, Avon Park, and Immokalee, respectively. Lowest $\Psi$ values were $-0.88 \pm 0.1,-1.10 \pm 0.06$, and $-0.93 \pm 0.08 \mathrm{MPa}$ under UF/IFAS treatments during dry seasons in Arcadia, Avon Park, and Immokalee, respectively, signifying water stress in the UF/IFAS irrigation scheduled compared with the other two irrigation schedules (Fig. 2). Stem water potential values increased during wet seasons because of precipitation by $13 \%, 16 \%$, and $22 \%$ in Arcadia, Avon Park, and Immokalee, respectively. Domingo et al. (1996) and Gasque et al. (2016) reported similar observations under water stressed and nonstressed lemon and citrus trees, respectively. These results elucidate the effect of different water management scenarios as a water stress factor. Thus, it is reasonable to conclude that Daily irrigation aids in maintaining trees with reduced stress and adequate moisture conditions.

Sap flow. Regardless of the season of sampling, ANOVA indicated significant changes in SF under different treatments across all sites. For example, irrigation treatments showed that the treatment, i.e., irrigation schedule $(P \leq 0.0011, P=0.0068, P=$ $0.0007)$, significantly affected citrus SF in Arcadia, Avon Park, and Immokalee, respectively (Table 3 ).

Generally, SF increased after sunrise, as expected, and reached maximum flow between 1200 and $1500 \mathrm{HR}$ of the day and declined thereafter reaching lower SF value at $2100 \mathrm{HR}$ (Figs. 3 and 4). Noticeable differences in diurnal patterns of SF were found under different treatments. Higher SF values were observed under Daily irrigation treatments compared with UF/IFAS or Intermediate treatments at all investigated sites. During the dry season, highest SF was measured under Daily treatment with values greater than IFAS treatments by $40 \%, 48 \%$, and $41 \%$ in Arcadia, Avon Park, and Immokalee, respectively. However, during the wet season, that gap has been reduced among all treatments with Daily irrigation treatment still presenting the highest SF values greater than Intermediate or IFAS treatments. Daily irrigation $\mathrm{SF}$ values were $44 \%, 32 \%$, and $37 \%$ greater than $\mathrm{SF}$ values under UF/IFAS treatments in Arcadia, Avon Park, and Immokalee, respectively. The shape of SF plots illustrated clear changes in the profile shape according to citrus tree water usage dynamics in the root zone. Fernandez et al. (2008) and Nadezhdina et al. (2007) indicated that the SF profile changed in response to $\mathrm{WC}$. They observed an increase in plants SF when TAW in the soil surface increased. Similar to our 
findings, various studies have reported positive correlations between diurnal SF and WC under different soil moisture conditions (Chen et al., 2014; Kadyampakeni et al., 2014; Xu et al., 2011; Yin et al., 2003).

Leaf area index. Leaf area index is the projected leaf area per unit of ground area $\left(\mathrm{m}^{2} \cdot \mathrm{m}^{-2}\right)$ (Pierce and Running, 1988). Significant differences were found in LAI among irrigation treatments across all sites and seasons (Table 3). Leaf area index of Daily irrigation treatment plots was significantly greater than UF/IFAS or Intermediate treatments by $23 \%$ and $16 \%$, respectively. Highest LAI values were observed under Daily treatments with averages of $4.8 \pm 0.4,3.3 \pm 0.3$, and $4.8 \pm 0.4$ in Arcadia, Avon Park, and Immokalee, respectively, in dry seasons. Increases in LAI by $8 \%, 26 \%$, and $8 \%$ were measured during wet seasons in Arcadia, Avon Park, and Immokalee, respectively. Across seasons, LAI values for UF/IFAS treatments represented significantly lower values compared with Daily treatment by $27 \%, 12 \%$, and $58 \%$ in dry seasons and $11 \%, 15 \%$, and $25 \%$ during wet seasons in Arcadia, Avon Park, and Immokalee, respectively. Lowest LAI values were $3.5 \pm 0.4,2.9 \pm 0.2$, and $2.1 \pm 0.2$ under UF/IFAS treatments during dry seasons in Arcadia, Avon Park, and Immokalee, respectively (Fig. 5). Daily irrigation schedule might have promoted dense canopy development through better use of soil nutrients and water compared with the other irrigation schedules because frequent irrigation has been known to reduce nutrient leaching.

\section{Conclusions}

Several conclusions can be drawn from this study. First, diurnal citrus HLB affected SF values under UF/IFAS and Intermediate treatments which were lower compared with Daily irrigation treatment, suggesting that the use of Daily irrigation treatment may be a better choice. Second, water relation parameters (TAW, SF, and $\Psi$ ) demonstrate the unique role that irrigation treatments play in regulating underlying soil layers. Finally, adopted irrigation schedules produced a clear differentiation within the same site, more research is needed on a number of aspects such as the effect of different irrigation treatments on soil characteristics (biological and physical) and nutrient dynamics in the soil profile.

\section{Literature Cited}

Ballester, C., J. Castel, L. Testi, D.S. Intrigliolo, and J.R. Castel. 2013. Can heat-pulse sap flow measurements be used as continuous water stress indicators of citrus trees? Irrig. Sci. 31:10531063, doi: 10.1007/s00271-012-0386-5.
Chen, D., Y. Wang, S. Liu, X. Wei, and X. Wang. 2014. Response of relative sap flow to meteorological factors under different soil moisture conditions in rainfed jujube (Ziziphus jujuba Mill.) plantations in semiarid Northwest China. Agr. Water Mgt. 136:23-33.

Dynamax. 1990. Dynagage installation and operation manual. Dynamax, Houston, TX.

Domingo, R., M.C. Ruiz-Sanchez, N.J. SanchezBlanco, and A. Torrecillas. 1996. Water relations, growth and yield of Fino lemon trees under regulated deficit irrigation. Irrig. Sci. 16:115-123.

Fereres, E. and V. Gonzalez-Dugo. 2009. Improving productivity to face water scarcity in irrigated agriculture, p. 123-143. In: V.O. Sadras and D.F. Calderini (eds.). Crop physiology: Applications for genetic improvement and agronomy. Academic Press, San Diego, CA.

Fereres, E. and M.A. Soriano. 2007. Deficit irrigation for reducing agricultural water use. J. Expt. Bot. 58:147-159.

Ferguson, J.F. 2015. Southwest Florida Water Management District, 2014 estimated water use report: Southwest Florida Water Management District.

Fernandez, J.E., S.R. Green, H.W. Caspari, A. Diaz-Espejo, and M.V. Cuevas. 2008. The use of sap flow measurements for scheduling irrigation in olive, apple and Asian pear trees and in grapevines. Plant Soil 305:91-104.

Garnier, M. and J.M. Bove. 1983. Transmission of the organism associated with citrus greening disease from sweet orange to periwinkle by dodder. Phytopathology 73:1358-1363.

Gasque, M., P. Marti, B. Beatriz Granero, and P. González-Altozano. 2016. Effects of long-term summer deficit irrigation on 'Navelina' citrus trees. Agr. Water Mgt. 169:140-147.

Gonzalez, P., J. Reyes-De-Corcuera, and E. Etxeberria. 2012. Characterization of leaf starch from HLB-affected and unaffected-girdled citrus trees. Physiol. Mol. Plant Pathol. 79:71-78.

Granier, A., D. Lousteau, and N. Breda. 2000. A generic model of forest canopy conductance dependent on climate, soil water availability and leaf area index. Ann. For. Sci. 57:755-765.

Hall, D.G. and T.R. Gottwald. 2011. Pest management practices aimed at curtailing citrus huanglongbing disease. Outlooks Pest Mgt. 22:189-192.

Hamido, S.A., K.T. Morgan, and K.A. Mahmoud. 2016. Citrus huanglongbing impact on citrus trees biomass and nutrients uptake. In: Annual soil science society conference. Division: Nutrient management and soil and plant analysis. $24 \mathrm{Feb}$. 2017. <https://scisoc.confex.com/scisoc/2016am/ webprogram/Paper99487.html $>$.

Handique, U., R.C. Ebel, and K.T. Morgan. 2012. Influence of soil-applied fertilizer on greening development in new growth flushes of sweet orange. Proc. Fla. State Hort. Soc. 125:36-39.

Holscher, D., O. Koch, S. Korn, and Ch. Leuschner. 2005. Sap flux of five co-occurring tree species in a temperate broad-leaved forest during seasonal soil drought. Trees 19:628-637.

Jagoueix, S., J.M. Bove, and M. Garnier. 1994. The phloem-limited bacterium of greening disease of the proteobacteria is a member of the alpha subdivision of the proteobacteria. Intl. J. Syst. Bacteriol. 44:379-386.

Jones, H.G. 2004. Irrigation scheduling: Advantages and pitfalls of plant-based methods. J Expt. Bot. 407:2427-2436.

Kadyampakeni, D.M., K.T. Morgan, A.W. Schumann, P. Nkedi-Kizza, and T.A. Obreza. 2014. Water use in drip- and microsprinkler-irrigated citrus trees. Soil Sci. Soc. Amer. J. 78:1351-1361.

Maupin, M.A., J.F. Kenny, S.S. Hutson, J.K. Lovelace, N.L. Barber, and K.S. Linsey. 2014. Estimated use of water in the United States in 2010: U.S. Geological Survey Circular 1405. 22 Dec. 2016. <http://dx.doi.org/10.3133/cir1405>.

Morgan, K.T., S. Barkataky, D. Kadyampakeni, R.C. Ebel, and F. Roka. 2014. Effects of short term drought stress and mechanical harvesting on sweet orange tree health, water uptake and yield. HortScience 49:835-842.

Morgan, K.T., T.A. Obreza, J.M.S. Scholberg, L.R. Parsons, and T.A. Wheaton. 2006. Citrus water uptake dynamics on a sandy Florida Entisol. Soil Sci. Soc. Amer. J. 70:90-97.

Nadezhdina, N., V. Nadezhdin, M.I. Ferreira, and A. Pitacco. 2007. Variability with xylem depth in sap flow in trunks and branches of mature olive trees. Tree Physiol. 27:105-113.

O'Brien, J.J., S.F. Oberbauer, and D.B. Clark. 2004. Whole tree xylem sap flow responses to multiple environmental variables in a wet tropical forest. Plant Cell Environ. 27:551-567.

Pierce, L.L. and S.W. Running. 1988. Rapid estimation of coniferous forest leaf area index using a portable integrating radiometer. Ecology 69:1762-1767.

Raithore, S., S. Dea, A. Plotto, J. Bai, J. Manthey, J. Narciso, M. Irey, and E. Baldwin. 2015. Effect of blending Huanglongbing (HLB) disease affected orange juice with juice from healthy orange on flavor quality. Lebensm. Wiss. Technol. 62:868-874.

SAS Institute. 2007. SAS system for Windows release 9.1.3. SAS Institute, Cary, NC.

Schaible, G.D. and M.P. Aillery. 2012. Water conservation in irrigated agriculture: Trends and challenges in the face of emerging demands, EIB-99, U.S. Department of Agriculture, Economic Research Service.

Singerman, A. and P. Useche. 2015. Impact of citrus greening on citrus operations in Florida. 19 Jan. 2017.<http://www.crec.ifas.ufl.edu/extension/ economics/pdf/Impact $\% 20$ Citrus $\% 20$ Greening\% 20web.pdf $>$.

Smith, D.M. and S.J. Allen. 1996. Measurements of sap flow in plant stems. J. Expt. Bot. 47:18331844.

Systat Software. 2009. SigmaPlot 12.3. Systat Software, Inc., San Jose, CA.

Xu, X., L. Tong, F. Li, S. Kang, and Y. Qu. 2011. Sap flow of irrigated Populus alba var. pyramidalis and its relationship with environmental factors and leaf area index in an arid region of Northwest China. J. For. Res. 16: 144-152.

Yin, G., G. Zhou, X. Wang, G. Chu, and Z. Huang. 2003. A study on sap flux density of two eucalyptus (Eucalyptus ueophylla) plantation in southeastern China by heat-pulse method. Acta Ecol. Sin. 23:1984-1990. 